\title{
Mobilidade e Evangelização: - Atendimento Pastoral de Brasileiros Católicos no Exterior: o exemplo de Boston - América do Norte
}

\author{
Orientador: Joel Portella Amado
}

Doutorando: Murialdo Gasparet

Área de Concentração: Teologia Sistemático-Pastoral

Linha de Pesquisa: Religião e Modernidade

Projeto de Pesquisa: Igrejas cristãs na grande cidade

A presente tese se propôs a analisar e responder, no âmbito teológico, como a Igreja Católica vive sua missão evangelizadora junto aos migrantes. Os processos migratórios podem ser experiências da vivência cristã, pois, em meio a percalços, sucessos e frustrações, podem possibilitar ao ser humano o encontro com Deus, em Jesus Cristo, na realidade concreta em que o ser humano se encontra. Assim, a Igreja Católica, na sua ação pastoral junto aos migrantes, deve ser marcada pela gratuidade, acolhida, misericórdia, justiça e pelo amor, fortalecendo o que há de melhor no ser humano. Para captar adequadamente o objeto material, isto é, a realidade da migração, a pesquisa optou por uma amostragem, centrando o foco das atenções na migração de brasileiros para uma região específica, a saber, Boston-Massachusetts-EUA. Através de pesquisa de campo, com perfil qualitativo, e do estudo bibliográfico das principais obras que tratam do assunto, buscou compreender o que ocorre com esta realidade migratória específica. Por ser uma tese teológica, o objeto formal foi recolhido no núcleo da experiência cristã, isto é, no encontro com Jesus Cristo e na adesão a uma comunidade eclesial e suas consequências. No encontro entre os dois objetos da pesquisa, percebeu-se a importância da relação entre fé e cultura, buscando compreender até que ponto a inserção numa nova cultura, no caso, a norte-americana, implica a perda ou a transformação da fé. As teorias migratórias e as conclusões teológicas revelaram valores e desafios para a Igreja Católica em sua missão evangelizadora, propondo ações concretas pastorais para e com os migrantes, independentemente 
do lugar onde estejam. O processo migratório analisado pela perspectiva da fé cristã induz a superação das estruturas rígidas e restritivas apresentadas como muros que cerceiam a liberdade e o sentido da existência humana num mundo diverso. É, pois, preciso, em lugar de muros, construir pontes de diálogos e de trocas que valorizem a vida. É preciso saber discernir entre o que pertence efetivamente à experiência cristã e o que é mediação cultural para a vivência da mesma.

Palavras-chave: Migração. Igreja Católica. Evangelização. 